\author{
Alar Läänelaid, Tomasz Ważny
}

\title{
RE-BOUND BOOK COVERS FROM THE ISLAND OF PIIRISSAAR, ESTONIA
}

\section{INTRODUCTION}

Along the eastern border of Estonia, on the coast of Lake Peipsi, there is a settlement area of an ethnic-religious group called Starovery or Staroobryadtsy (meaning Old Believers or Old Ritualists). The history of the Old Believers extends back to the $17^{\text {th }}$ century when, after the Russian Orthodox Church reforms between 1652 and 1666, they separated from the official church and continued their traditional liturgical practices. The church reforms were accompanied by serious repressions against the conservative Orthodox branch who refused to follow the new liturgy rules. The repressive methods employed against the Old Believers in Russia included trials, executions, deportations and the confiscation of their property. Old Believers escaped to remote uninhabited areas of the Russian Empire and to neighbouring countries. In the $17^{\text {th }}$ century, they also reached Rzeczpospolita (which included parts of present-day Poland, Belarus, Lithuania, Ukraine and Russia) ${ }^{1}$. The Old Believers were quite literate, as they had preserved

1 Grigorii Potashenko, Russkie staroobryadtsy v Velikom knyazhestve Litovskom: stanovlenie drevnepravoslavnoi traditsii (2007): http://samstar-biblio.ucoz.ru/publ/52-1-0-888 (In English: Russian Old Believers in the Grand Duchy of Lithuania: Formation of Tradition of Russian Old Orthodox Church) [viewed 23.11.2017]. 
and taken their old church books with them. By the early $18^{\text {th }}$ century the Old Believers already suffered from a shortage of literature and the first underground printing presses appeared in Lithuania and Poland. Despite censorship by the church, the Old Believers started having their books printed by Uniate printers in Vilnius, Supraśl, Pochaev, and also in the state and private printing houses in Grodno (Royal Printing House), in Warsaw (Düfor Printing House), Lviv and Klincy (underground printing houses of the Old Believers). The earliest known printed Old Believers' books were published in the early $18^{\text {th }}$ century in Mogilev ${ }^{2}$. As the Old Believers only used prereform books in their liturgy, their printing production consisted mainly of reprints of the books published in Russia from 1555 to $1653^{3}$ The repressions of Old Believers in Russia continued for a long time. The first legal Old Believers' printing house (Simakov's) in Russia was established in 1905. The sects and communities of Old Believers actively communicated among themselves and distributed books and icons (religious paintings). The icons were painted on wooden panels and leather bindings with wooden covers were the traditional type of book binding. When the Old Believers were forced to escape from the repressions, they took their books and icons with them.

The first Old Believers reached Estonia in the late $17^{\text {th }}$ century and settled on the west coast of Lake Peipsi near Mustvee and Kallaste ${ }^{4}$ At the end of $18^{\text {th }}$ century a number of Old Believers arrived in the coastal villages on Lake Peipsi from the Vitebsk region, and the Novgorod and Tver provinces. Old Believers' congregations also exist in other parts of Estonia. In 1920-1930 there were a total of about 10,000 Old Believers in Estonia, who belonged to 12 congregations.

The island of Piirissaar, with an area of $7.5 \mathrm{~km}^{2}$, is the largest island in Lake Peipsi, which is on the border between Estonia and Russia. The permanent settlement in the island is said to date back to the $17^{\text {th }}$ century, when escapees from the Czarist military and Old Believers escaping religious persecution settled the island. Currently, there are about 50 permanent residents on the island, most of them are

2 Andrei Voznessenski, Kirillicheskie izdaniya staroobryadcheskikh tipografii kontsa XVIII nachala XIX: Katalog (Leningrad, 1991). (In English: Issues of Print Shops of Old Believers i Cyrillic from the End of $18^{\text {th }}$ to the Beginning of $19^{\text {th }}$ Century: a Catalogue).

3 Larissa Petina, personal communication by e-mail (2017).

4 Vanausulised Eestis (2017): https://et.wikipedia.org/wiki/Vanausulised_Eestis (In English Old Believers in Estonia) [viewed 23.11.2017].
Old Believers. Most of the people are fishermen and onion-growers. There is an Orthodox church on the island and an Old Believers' chapel (house of prayer).

On 16 May 2016 the Old Believers' house of prayer in Piirissaar was destroyed by fire. In the summer of 2016, conservators from the National Archive restored three damaged books that were saved from the fire. Several other books were still being restored. In autumn 2016 specialists of several museums and universities of Estonia started to preserve the damaged cultural items from the house of prayer ${ }^{5}$.

One of these books was so extensively damaged by the fire that its covers had to be replaced with new ones by the book restorers ${ }^{6}$. That was the $3^{\text {rd }}$ edition of Mineia for February that was printed in Moscow in $1879^{7}$. The half-charred wooden covers were submitted to one of the co-authors of this article for study. There is a great deal of experience in the dendrochronological dating of wooden covers in France ${ }^{8}$. Oak has been the preferred wood for book covers in France between the $8^{\text {th }}$ and $15^{\text {th }}$ centuries ${ }^{9}$. Therefore, we attempted to date the covers. Previously, dendrochronology has been used to date the oak panels of paintings in Estonia ${ }^{10}$ and in Finland ${ }^{11}$. The dendrochronological investigation revealed the unexpectedly old age of these covers from Piirissaar.

5 Jaan Lehtaru, "Piirissaare palvemaja raamatute päästmine ja konserveerimine", Rahvusarhiiv ajaveeb (09.09.2016): https://blog ra ee/2016/09/09/piirissaare-palvemaja-raamatute-paastmineja-konserveerimine (In English: Saving and Conservation of Books of the Piirissaar House of Prayer) [viewed 23.11.2017].

6 Tulvi-Hanneli Turo, Piirissaare kirikuteenistuse raamatu "Mineja služebnoe, fevral" konserveerimistööde album (Tallinn: Tallinna Linnaarhiiv, 2017), 17. (In English: Conservation of the Piirissaar church service book "Mineja sluzhebnoe").

7 Petina, personal communication by e-mail (2017).

8 Catherine Lavier, "The diversity of dendrochronological investigations in France and links with other European laboratories", Tree-ring Dating and Dendroclimatology. Proceedings of Wha

9 Catherine Lavier, Georges Lambert, "Dendrochronology and works of art", Tree rings, Environment and Humanity, ed. by Jeffrey S. Dean, David M. Meko, Thomas W. Swetnam. Proceedings of the International Conference: Tucson, Arizona, May 17-21, 1994 (Tucson University of Arizona, 1996), 543-556.

10 Alar Läänelaid, Alar Nurkse, "Dating of a $17^{\text {th }}$ Century Painting by Tree Rings of Baltic Oak", Baltic Forestry, 12 (1) (2006), 117-121.

11 Samuli Helama, Alar Läänelaid, Maija Santala, Ari Tanhuanpää, "Dendrochronological dating of wooden artifacts by measuring the tree rings using a magnifying glass and photographyassisted method: an example of a Dutch panel painting", Archaeological and Anthropological Sciences, 8 (1) (2016), 161-167. 


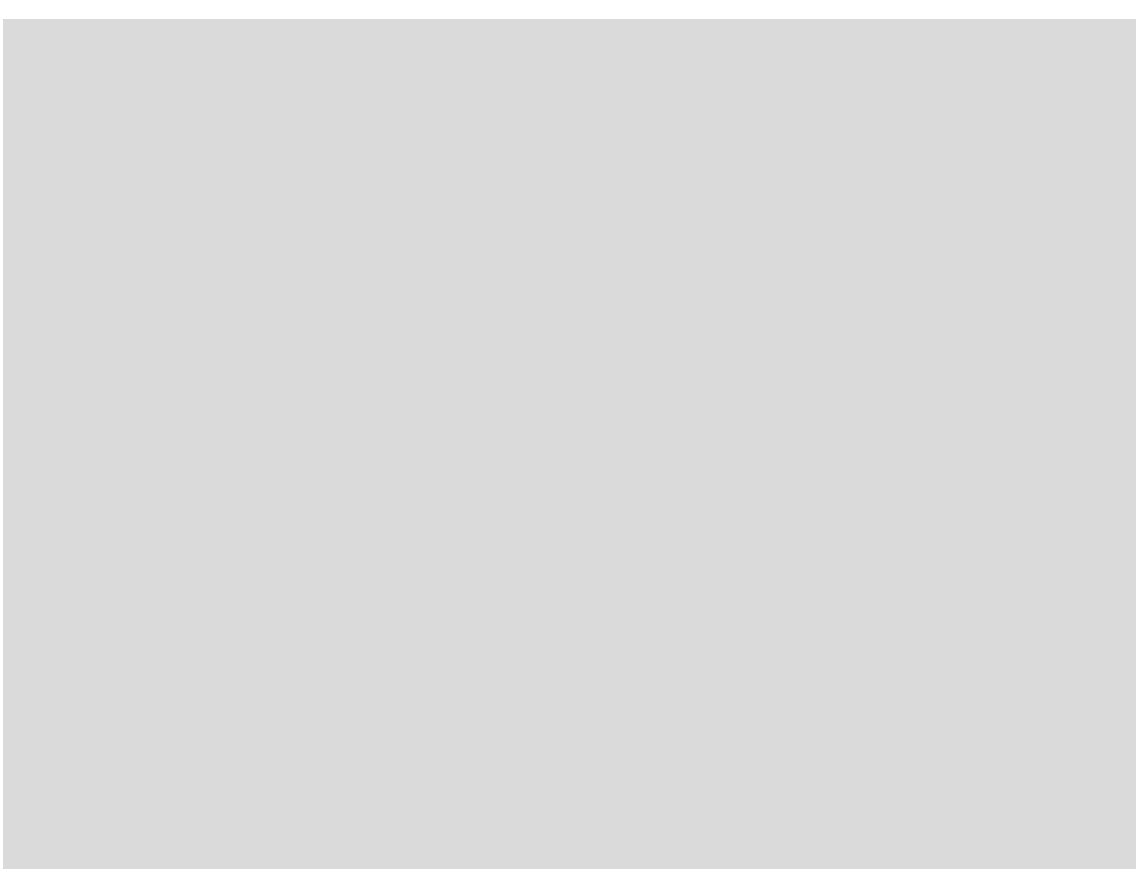

Fig. 1. The fire-damaged wooden covers (left: front cover) from the Mineia for February from the Piirissaar house of prayer. The widths of the tree rings on the bottom edges of

\section{MATERIAL AND METHODS}

The leather-covered wooden covers came from a service book called Mineia for February, $3^{\text {rd }}$ edition, 334 pages, printed in 1879 (7387) in the Old Believers' printing house (Tip Jedinovercev) in Moscow. The colophon says that the (original) book was printed in 1645 (7153) in Moscow by the Pechatnyi Dvor Printing House ${ }^{12}$.

The half-charred wooden book covers were obtained from book restorer Tulvi Turo for dendrochronological investigation. The size of the covers was $360 \times 245 \times 7.5 \mathrm{~mm}$ (Fig. 1). Note that the size of the boards decreased somewhat due to combustion and smoothing the edge of the covers. After cutting the edge of the cover boards it was clear that the covers were made of oak (Quercus sp.). It also appeared that both boards were widened with a ca 2-cm-wide oak slat glued along the back edge of the boards. The boards were cut more or less in radial direction of the tree trunk. Treatment with

12 Petina, personal communication by e-mail (2017)

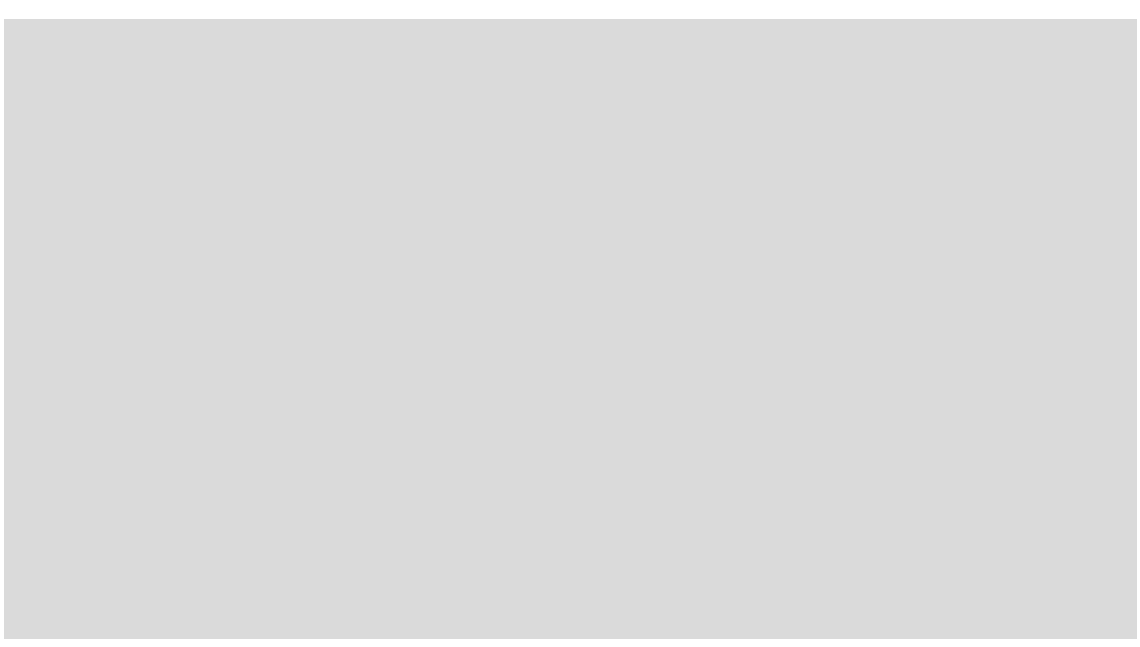

Fig. 2. Synchronous position of tree-ring series of the front cover (0EQPIIID) and back cover (OEQPII2C) with each other and in time scale (overlap 89 years, TVH $=5.2$ ).

white chalk helped to raise the contrast of tree rings in the board edges. The ring widths in both cover boards were measured using a Lintab measuring device (Rinntech) and stereomicroscope Leica S4E in $0.01 \mathrm{~mm}$ units $^{13}$. To ensure the correctness of the measurements, both panels were remeasured using 10× Eschenbach measuring lens with $0.1 \mathrm{~mm}$ scale units and built-in LED light.

The tree-ring series of the two cover boards were synchronized to join them into an averaged tree-ring series of the book covers (Fig. 2) with an extent of 108 years. The averaged tree-ring series was synchronized with dozens of European oak chronologies in the Catras program ${ }^{14}$. The program compares time series of tree rings (the series under study and a reference series) pairwise, moving them by one-year step in relation to each other. In each position two statistical similarity indices are calculated: Student's t-criterion and Gleichläufigkeit, i.e. percentage of same direction year-to-year changes in the two series ${ }^{15}$. For the latter, the significance level is determined,

13 Rinntech, Technology for tree and wood analysis: http://www.rinntech.de/index-28703. html [viewed 23.11.2017].

14 Roland W. Aniol, "Tree-ring analysis using CATRAS", Dendrochronologia, 1 (1983), 45-53. 15 Multilingual Glossary of Dendrochronology. Terms and Definitions in English, German, French, Spanish, Italian, Portuguese, and Russian, comp. by Michele Kaennel, Fritz H.
Schweingruber (Berne, Stuttgart, Vienna: Haupt, 1995), 467 . 
being either 95.0, 99.0 or 99.9. The position of the series under study at the highest similarity with reference and after visual verification of tree-ring curves indicates the date of the series.

Another wooden cover saved from the Piirissaar fire was also received for dendrochronological investigations from Tiia Nurmsalu, a book restorer at the University of Tartu Library. It is the back cover of the Mineia for April, made of oak and charred on one corner. The book, Mineia for April, was also printed in 1879 at the same printing house (Tip Jedinovertsev) as the Mineia for February ${ }^{16}$.

\section{RESULTS}

There are two native oak species growing in the Pomeranian area: the European oak Quercus robur L. and the Durmast oak Q. petraea Liebl. Fritz H. Schweingruber says that "The wood of these two species cannot be differentiated on the basis of their anatomic characteristics."17 So the covers are probably made of one of these oak woods.

It was established that the covers consisted of oak boards widened with 2-cm-wide oak slats glued to the spine side edge of the covers. Both oak boards have 98 measured tree rings; besides, the glued oak slats contained 25 narrow rings in the front cover and 7 wide rings in the back cover (Fig. 3). There was no lighter sapwood in either the oak boards or the slats. The sapwood rings were entirely removed for the production of the boards, as were the rings close to the pith. Sapwood rings are generally removed when manufacturing fine boards for painting panels because they are softer and more susceptible to insect damage and decomposition than the more resistant heartwood ${ }^{18}$. The series of the covers end on different dates. The averaged series of the two boards had extended 108 years, as the board series are at 9 years distance in relation to each other in their synchronous position.

16 Tiia Nurmsalu, personal communication by e-mail (2017).

17 Fritz H. Schweingruber, Trees and Wood in Dendrochronology. Morphological, Anatomical, and Tree-Ring Analytical Characteristics of Trees Frequently Used in Dendrochronology (Berlin, Heidelberg: Springer-Verlag, 1993), 402.

18 Aoife Daly, Alar Läänelaid, "The dendrochronological dating of three paintings in the style of Bosch/Bruegel", On the Trail of Bosch and Bruegel. Four paintings United under Cross examination, ed. by Erma Hermens (National Gallery of Denmark and CATS, Copenhagen,
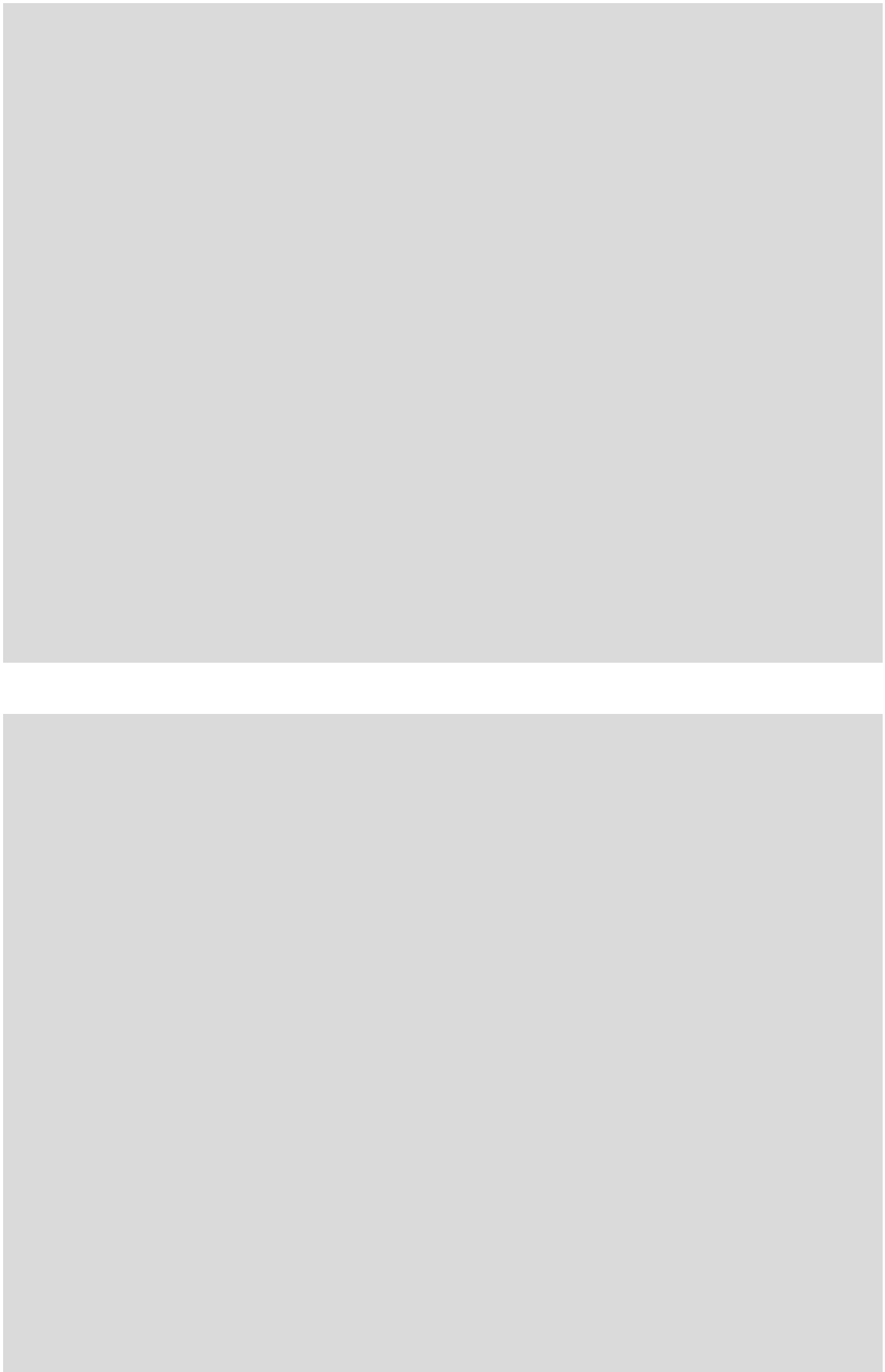

Fig. 3. The glued oak slats on the edge of the front cover (above) and back cover (below) Slats can be distinguished by non-fitting tree-ring pattern. The upper photo shows insect holes both in the board and the slat. Photos: Alar Läänelaid. 


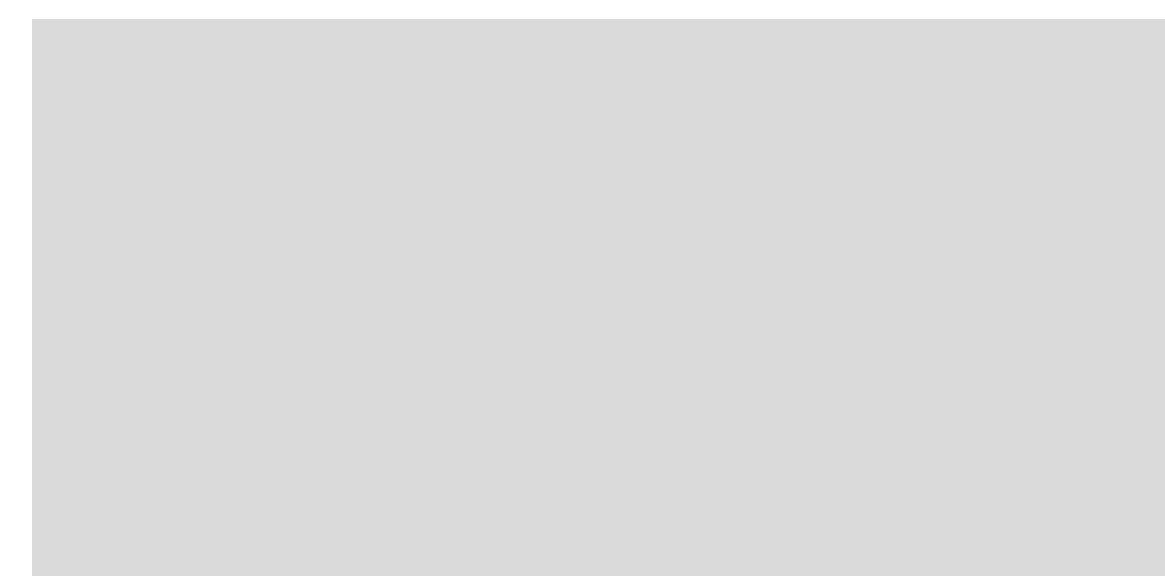

Fig. 4. Average tree-ring series of the oak boards of the Piirissaar covers of Mineia for February in synchronous position with East Pomerania oak chronology (Ważny, East Pomerania oak chronology pola006, AD 996-1985). Overlap 108 years, Student's $\mathrm{t}=5.28$, Gleichläufigkeit
64.0 at significance level 99.0 . Abscissa - calendar years, ordinate - ring widths.

Contrary to expectation the tree ring series of the February book did not appear similar to the $19^{\text {th }}$ century oak chronologies. The tree-ring series of the book covers appeared to be most similar to East Pomerania oak chronolog $\mathrm{y}^{19}$ in the position where the last year of the book cover series is dated AD $1353(t=5.28$, Fig. 4). Local object chronologies confirmed this geographical area. This is the dendrochronological date of the Piirissaar Mineia for February covers, the case when sapwood the outer (and youngest) part of the tree - is totally lacking.

Investigation of the back cover of Mineia for April resulted in the dendrochronological date of the cover being AD 1857, with East Pomerania oak chronology (overlap 116 years, $\mathrm{t}=4.83$, Gleichläufigkeit 62.2 at significance level 99.0). The oak board contains 94 rings in one end and 116 rings in another end grain, including 11 sapwood rings in this end. This cover has no glued slats on the margins.

\section{DISCUSSION}

Let us try to interpret the dating results for the covers of the Mineia for February from Piirissaar in time and space. The early date that was obtained might be explained by re-binding while the geographical region refers to the journeys made by the book and the covers.

19 Tomasz Ważny, East Pomerania oak chronology pola006, AD 996-1985 (1986) https://www.ncdc.noaa.gov/paleo-search/study/5214 [viewed 23.11.2017].
The dendrochronological date AD 1353 for an item without sapwood means that an unknown number of sapwood rings has been cut of from the edge of the oak boards. There is some evidence about the sapwood amount in oaks grown in Europe. It was established that there were 9 to 36 sapwood rings in the oaks growing in Poland. On average, the oaks in Poland contain 15 sapwood rings, and in the $90 \%$ confidence interval the number of sapwood rings was 9 to $24^{20} 2122$. Besides, some heartwood rings may have been lost in the course of processing the oak boards. The date difference of the front and back cover boards, i.e. 9 years, indicates the possible ring loss. Thus, let us add 9 tree rings of heartwood to the dendro-date: $1353+9=1362$ Considering the maximum number of sapwood rings to be 24 , the date of the waney edge of the oak would be $1362+24=1386$. As the timber for valuable objects like book covers and painting panels was well seasoned, the drying period should be added to the dendrodate. We do not know the exact number of years of the seasoning period in the $14^{\text {th }}$ and $15^{\text {th }}$ centuries, but the seasoning and preparation time was longer than in the $17^{\text {th }}$ century - usually between 10 and 15 years $^{23}$. Assuming the minimum seasoning period for our book covers, the covers were manufactured in $1362+10=1372$ at the earliest (terminus post quem). Pomeranian oaks have approximately 15 sapwood rings. Thus, the addition of the average 15 sapwood rings, plus an average of $\mathbf{1 0 - 1 5}$ years for seasoning puts the date at AD 1368-1373. The number of missing heartwood rings is unknown but it should be relatively small because of the high value of oak timbers. Anyway, we are not mistaken when we say that these covers were manufactured in the end of the $14^{\text {th }}$ century.

20 Tomasz Ważny, Aufbau und Anwendung der Dendrochronologie für Eichenholz in Polen. PhD Dissertation (Hamburg: University of Hamburg, 1990), 213. (In English: Construction and Application of Dendrochronology for Oak Wood in Poland).

21 Kristof Haneca, Tomasz Ważny, Joris Van Acker, Hans Beeckman, "Provenancing Baltic timber from art historical objects: success and limitations", Journal of Archaeological Science, 32 (2005), 261-271.

22 Kristof Haneca, Katarina Čufar, Hans Beeckman, "Oaks, Tree-rings and Wooden Cultura Heritage: a Review of the Main Characteristics and Applications of Oak Dendrochronology in Europe", Journal of Archaeological Science, 36 (2009), 1-11.

23 Dieter Eckstein, Josef Bauch, "Dendrochronologie und Kunstgeschichte - dargestellt an Gemälden holländischer und alt-deutscher Malerei", Mitt. Dtsch. Dendrol. Ges., 67 (1974), 234-243. (In English: Dendrochronology and Art History: Shown on Paintings of Dutch and Old German Painters). 
Regarding the region of origin for the covers of the book printed in Moscow, the adventurous history of the Old Believers has to be taken into account. In the $17^{\text {th }}$ century, in the course of the Orthodox Church reforms in Russia, severe repressions forced the conservative religious groups to migrate to the border areas of the Czarist empire and outside, including Rzeczpospolita.

This specific Mineia book was printed in 1879 in Moscow ${ }^{24}$. We do not know what covers were used to bind the fresh-printed book. We cannot be sure that the old used Polish covers were used by the bindery in Moscow. As the repressions against Old Believers in Russia continued, according to one account, the book was probably taken by migrating Old Believers to East Pomerania, and the damaged printed matter was re-bound there by re-using old $14^{\text {th }}$ century wooden covers. Then the book travelled together with Old Believers to Estonia. Additionally, the presence of the glued oak slats on the edges of both covers refers to a need to widen the cover boards for a new binding and confirms the application of reused boards. Unfortunately, the slats are not dendrochronologically datable due to the insufficient number of tree rings in them. It is noteworthy that these covers originate from the pre-Gutenberg era, thus the original book between them must have been a hand-written, and not a printed, book.

Another version would be that the Moscow-printed book was re-bound in Piirissaar, using old wooden covers from a Polish book. Then how would Polish book covers have arrived in Estonia? From the correspondence of Valentina Aman, the granddaughter of the former Old Believers' priest named Smirnov in Piirissaar, we learn that before World War II an Old Believers' family named Sosnitski had been living in the nearby Pedaspää (Sosnitsi) village on the west coast of Lake Peipsi. The Sosnitski family supposedly emigrated from Poland in the $17^{\text {th }}$ century. It is possible, although not proven, that these books belonged to the Sosnitski family ${ }^{25}$. In that case, the Sosnitski family may have used the old East Pomeranian covers to re-bind the service book printed in Moscow.

In any case, the fact that $14^{\text {th }}$ century East Pomeranian covers were used to bind a book printed in Moscow in the $19^{\text {th }}$ century and saved from fire in $21^{\text {st }}$ century Estonia, shows the lively and often dramatic

24 Petina, personal communication by e-mail (2017)

25 Valentina Aman, personal communication by e-mail (2017).

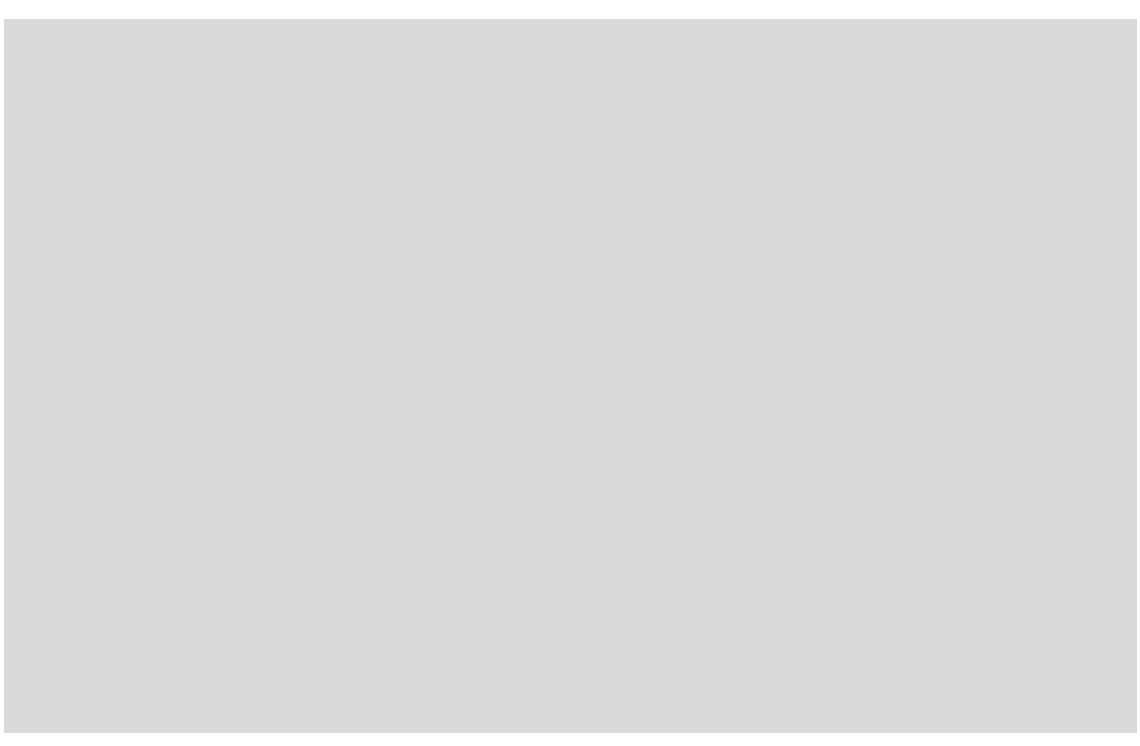

Fig. 5. The possible journey of the wooden covers and book on the route Gdansk-MoscowPiirissaar (Estonia). The route and the distance shown runs along today's roads. It is .

relations that existed between the Old Believers' congregations in these countries during several centuries (Fig. 5). Due to fire in the house of prayer we have discovered oak covers that are now about 600 years old.

The dendrochronological date of the back cover of Mineia for April can be interpreted by taking into account the number of the preserved sapwood, i.e. 11 rings. Considering the average sapwood ring number in Poland to be 15, the waney edge of this oak should be dated as $1857+4=1861$. Adding the seasoning years of the oak board, i.e. 2 to 8 years, the probable date for the use of this board for bookbinding is ca 1863 to 1869 or later (in the case of a larger number of sapwood rings). The year for the printing of this book is $1879^{26}$ The time gap can be explained by a larger than average number of sapwood rings. Indeed, sapwood rings of this board are very narrow and a larger number is possible. In any case, this cover is not from the same epoch as the covers of the Mineia for February. It seems to be contemporary with the book bound in it. The date of this cover shows that the bindings of the Mineia books of the Piirissaar Old Believers' house of prayer were of different origins.

26 Nurmsalu, personal communication by e-mail (2017). 


\section{CONCLUSIONS}

The service books of Old Believers, called Mineia and rescued from the fire in Piirissaar house of prayer in Estonia, were restored by Estonian restorers. The heavily damaged wooden covers of the Mineia for February were submitted for dendrochronological investigation. It was determined that these oak covers originate from late $14^{\text {th }}$ century East Pomerania. However, the book was printed in 1879 in Moscow, and this can only be explained by secondary use the old pre-Gutenberg era covers to bind a newer book. The geographical origin of the covers relates to the dramatic history of the Old Believers sects. Another wooden cover, from Mineia for April, produced a dendrochronological date of AD 1857 that coincides with the printing time of the book in 1879.

Alar Läänelaid, Tomasz Ważny: Re-Bound Book Covers from THE Island of PiIRISsaAr, Estonia

Keywords: Wooden Covers; Dendrochronology; Old Believers; BOOK History

\section{SUMMARY}

Old Believers' service books from the Piirissaar house of prayer in Estonia were rescued from a fire and the damaged oak boards of the wooden covers of one of the books were dendrochronologically dated back to AD 1353. The dendrochronological reference shows that the oak wood originates from East Pomerania-Gdansk region. The intriguing fact is that the book was not printed until 1879 in Moscow. The seemingly contradictory dates and locations can be explained by the adventurous history of the Old Believers sects in Russia. The Old Believers were suppressed during the Russian Orthodox Church reforms between 1652 and 1666 and many of them escaped to remote marginal areas of the empire or emigrated, e.g. to Rzeczpospolita. Due to lively communication between the Old Believers' congregations, their literature moved from country to country. In this case, a newer book of the Old Believers was bound with old wooden covers from Poland.

\section{CV}

Dr. Alar Läänelaid (b. 1951) is Associate Professor in Landscape Ecology at the University of Tartu, Estonia. He has dendrochronologically dated a number of architectural objects, as well as painting panels and sculptures.

Dr. Tomasz Ważny (b. 1957) is Associate Research Professor of Laboratory of Tree-Ring Research at the University of Arizona in the U.S., and a Faculty Member of the Faculty of Fine Arts at Nicolaus Copernicus University in Torun, Poland. He has dendrochronologically dated many archaeological and architectural objects and art objects in Poland, Central Europe and the Mediterranean area. 
